\title{
Dioecy in Flowering Plants: From the First Observations of Prospero Alpini in the XVI Century to the Most Recent Advances in the Genomics Era
}

\author{
Alessandro Vannozzi ${ }^{+}\left(\mathbb{D}\right.$, Fabio Palumbo $^{+}\left(\mathbb{D}\right.$, Margherita Lucchin $^{(D)}$ and Gianni Barcaccia $*$ (D)
}

check for

updates

Citation: Vannozzi, A.; Palumbo, F.; Lucchin, M.; Barcaccia, G. Dioecy in Flowering Plants: From the First Observations of Prospero Alpini in the XVI Century to the Most Recent Advances in the Genomics Era. Agriculture 2022, 12, 364. https:// doi.org/10.3390/ agriculture12030364

Academic Editor: Aimin Zhang

Received: 8 February 2022

Accepted: 2 March 2022

Published: 3 March 2022

Publisher's Note: MDPI stays neutral with regard to jurisdictional claims in published maps and institutional affiliations.

Copyright: (C) 2022 by the authors. Licensee MDPI, Basel, Switzerland. This article is an open access article distributed under the terms and conditions of the Creative Commons Attribution (CC BY) license (https:// creativecommons.org/licenses/by/ $4.0 /)$.
Department of Agronomy, Food, Natural Resources, Animals and Environment (DAFNAE), Campus of Agripolis, University of Padova, V. le dell'Università 16, 35020 Legnaro, Italy; alessandro.vannozzi@unipd.it (A.V.); fabio.palumbo@unipd.it (F.P.); margherita.lucchin@unipd.it (M.L.)

* Correspondence: gianni.barcaccia@unipd.it

† These authors contribute equally to this work.

\begin{abstract}
Prospero Alpini was an Italian physician, botanist and scientist. Born in Marostica, in the Republic of Venice, in his youth he served in the Milanese army, but in 1574 he decided to study medicine at the University of Padova, where he graduated in 1578. After a short period as a doctor in Camposampiero (Padova, Italy), he became the personal doctor of Giorgio Emo, the appointed consul in Cairo in Egypt. In this way, he was able to devote himself to the study of botany. In this country, from the cultivation practices of the date palm, he described for the first time the sexual dimorphism in plants, later adopted as the basis of Linnaeus' scientific classification system. Since then, this behavior, termed dioecy, has been described in other plant species, and many advances have been made in understanding the molecular mechanisms underlying this phenomenon, especially with the advent of genomics. Starting from a brief description of Prospero's life and his pioneering scientific contribution, we illustrated the two main models explaining dioecism. This was achieved by taking a cue from two plant species, grapevine and poplar, in which genomics and single molecule sequencing technologies played a pivotal role in scientific advance in this field.
\end{abstract}

Keywords: Phoenix dactylifera; Vitis spp.; Populus spp.; sex-determining region; hermaphroditism

\section{Prospero Alpini and the History of Dioecy}

Prospero Alpini, also known as Prosper Alpinus, Prospero Alpino or Prosper Alpin, was born in Marostica (Vicenza, Italy) on 23 November 1553. Son of the doctor Francesco Alpini and Bartolomea Tarsia of Padua, he was addressed in his youth to a military career, which after a short time he left to enroll at the University of Philosophers and Doctors in Padua, where he graduated in 1578 in medicine and began to practice the profession in Camposampiero (Padua, Italy). On 21 September 1580, he left for Cairo at the behest of the Venetian patrician Giorgio Emo, who had been sent by the Venetian Republic as a consul in Egypt. Alpini stayed in Egypt for about three years, and in November 1584 he returned to Venice, where the prince of Melfi Giovanni Andrea Doria hired him as his personal doctor and took him to Genoa. In 1590, Alpini found himself in Venice again and his botanical works allowed him to receive the professorship "Ad lecturam simplicium" at the University of Padua in 1594. A few years later, in 1603, he was appointed prefect of the botanical garden. Despite suffering from serious illnesses, he remained dedicated to all his assignments until his death on November 23, 1616. His works deal with his two main passions, medicine and botany. After his trip to Egypt, Alpini became passionate about this branch of biology, so much so that he wrote several texts relating to the native Egyptian flora and its uses in the medical field. In 1592, he published the work De plantis Aegypti liber, structured in a dialogical form with the imaginary interlocutor Melchiorre Guilandino, the first professor of botany at the University of Padua (1567). In De plantis Aegypti, together 
with a detailed description of Egyptian plants and their use in the medical field, we can also read the observations of Alpini regarding the fertilization of some species: in chapter VII he describes how the Egyptians promoted the assisted fertilization of the date palm (Phoenix dactylifera) to produce fruit of better size (Figure 1). The Egyptians in fact used to link the male flowers of this dioecious species to the female ones, and the close contact between the two flowers of opposite sex favored a better fertilization. In this sense, Prospero Alpini can be considered the first scientist to write about assisted cross fertilization between dioecious species. Below is a translation of some parts of the text "De Plantis Aegypti".
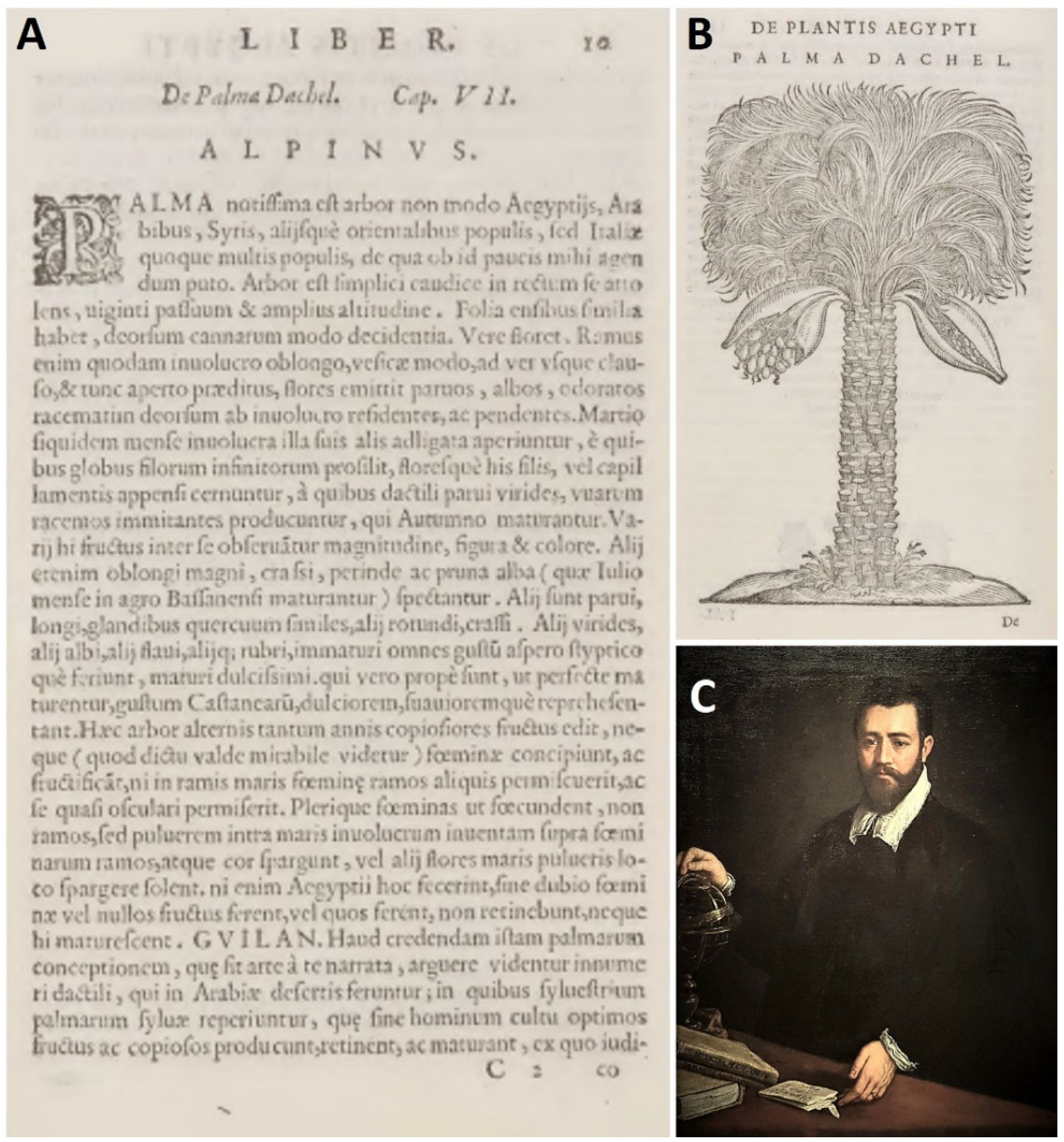

Figure 1. (A) A picture of the first page of Chapter VII of "De Plantis Aegypti liber". Reprinted from ref. [1]; (B) Graphic representation of the date palm as reported by Prospero Alpini. Reprinted from ref. [1]; (C) Portrait of Prospero Alpini from 1586, by Leandro Bassano, Staatsgalerie, Stuttgart.

[...] Hæc arbor alternis tantum annis copiofiores fructus edit, neque (quod dictu valde mirabile videtur) forminae concipiunt, ac fructificat, ni in ramis maris focmine ramos aliquis permifcuerit, ac se quasi osculari permiferit. Plerique fominas ut focundent, non ramos, sed pulurem intra maris inuolucrum inuentam supra fomi narum ramos, atque cor spargunt, vel alijflores maris pulueris loco spargere solent. ni enim Aegyptii hoc fecerint, fine dubio formi næ vel nullos frudus ferent, vel quos ferent, non retinebunt, neque ni maturescent. [...]
[...] This tree produces abundant fruit only in alternate years, and (which seems to be very admirable) females conceive and bear fruit only if someone has grafted the branches of the female into the branches of the male and allowed them to kiss. Some do not use the branches to fertilize the females, but the dust found on them, while others usually scatter the flowers of the male instead of the dust. In fact, if in fact the Egyptians did not do this, the females either do not produce any fruit, or those who produce will not keep them and these will not reach maturity. [...] 


\section{Dioecy in Angiosperms}

According to the World Flora Online (WFO), a compendium of the world's plant species, around 350,000 plant species have been so far cataloged [2]. Among them, several taxa evolved by organizing their reproductive organs (male and female) on distinct individuals. This sexual system takes the name of dioicy if the tissues producing female and male gametes (archegonia and antheridia, respectively) are carried by separate gametophytes (i.e., in the case of bryophyte); the term "dioecy" is instead used if the two reproductive organs are produced on separate sporophytes (i.e., seed plants, including angiosperms and gymnosperms) [3].

The fraction of dioicous/dioecious species is extremely variable. According to the estimates provided by Villarreal and Renner [4], non-vascular land plants (i.e., bryophytes) seem to be characterized by percentages of dioicous species ranging from $40 \%$ (Anthocerotophyta, e.g., hornworts) to $68 \%$ (Bryophyta, e.g., mosses). Dioecy seems to even be predominant in gymnosperms for which Walas and colleagues estimated $65 \%$ of species carrying male and female flowers separately [5]. By contrast, this sexual system is relatively uncommon in angiosperms; a recent review estimated that 15,600 dioecious plants were well distributed in $43 \%$ of angiosperm families but represented only the $5-6 \%$ of the angiosperms species [6].

The rare occurrence of dioecy in flowering plants is considered the consequence of two main disadvantages: the lack of reproductive assurance of individuals and the fact that virtually only half of the population (female plants) can carry the seeds and produce offspring [7]. This led to the hypothesis that this behavior could be considered an evolutionary dead end of angiosperms with higher probabilities of extinction and lower diversification rates [8]. However, in the last few years some studies started to overturn such hypotheses [7]. The dispute remains open also because it is still unknown whether the ancestral angiosperm had unisexual or bisexual flowers. According to the most accredited hypothesis, all angiosperms (including dioecious) are likely to derive from a hermaphrodite or monoecious ancestor [9,10], as would confirm Amborella trichopoda, the living sister lineage to all remaining flowering plants, which is dioecious but with stamen residues in the female flowers [11].

Assuming therefore that dioecy does not represent the ancestral condition of angiosperms, it can be stated, with a certain safety margin, that this sexual system has originated independently multiple times in different families, similarly to other sexual behaviors (e.g., apomixis) [12]. In support of this is not only the fact that dioecy and monoecy coexist within hundreds of families but also that, within the same family, there are simultaneously cases of male and female heterogamety. Heterogametic sex or digametic sex is the condition in which sexual chromosomes are different [13]. We distinguish between male heterogamety $(X X / X Y)$ - where male individuals carry different sex chromosomes (XY) - and female heterogamety (ZW/ZZ). Several genera including Populus and Salix (Salicaceae) [14,15], Silene (Caryophyllaceae) [16] and Dioscorea (Dioscoreaceae) [17] present both species with $X X / X Y$ and $Z W / Z Z$ sexual systems, suggesting the concrete possibility that shifts between different sex chromosome systems $(X Y \leftrightarrow Z W)$ are feasible not only within the animal kingdom-where multiple cases have been reported in several phyla $[18,19]$ —but also in plants [16,17].

\section{Models for Sex Determination in Angiosperms}

Studies aimed at investigating the genetic determinants behind the angiosperms dioecy have been greatly facilitated by the recent advances in molecular techniques. Based on this and depending on whether the ancestor was hermaphroditic (perfect flowers in each plant) or monoecious (coexistence of male and female flowers in each plant), different theories have been suggested to explain the origin of dioecy. According to the original hypothesis proposed by Charlesworth and Charlesworth in the late 1970's, to switch from a hermaphrodite to a dioecius state, two distinct mutations affecting male and female gametes production are required [20]. A first recessive mutation affects pollen development and 
leads to an intermediate condition of gynodioecy, which is the coexistence of female (i.e., male-sterile individuals) and hermaphrodite individuals. A second dominant mutation affects ovule production in hermaphrodite plants leading to male plants (i.e., female-sterile individuals). The opposite situation (based on an intermediate condition of androdioecy) is possible too, although there is a striking rarity of androdioecy relative to gynodioecy [21] Clearly, for the correct functioning of a two-gene model (TGM)-based dioecism, the species must set a mechanism capable of preventing recombination between the two independently mutated genes, avoiding the generation of hermaphrodites and asexual individuals. TGM still seems to fit for some species, including kiwis [22], grapevines [23] and the date palm itself [24], the object of the first observations on dioecy by Prospero Alpini.

For other plant taxa, including poplar [25], persimmon [22] and spinach [26], a single gene model (SGM) seems to explain better the switch from hermaphroditism to dioecy. In $\mathrm{XX} / \mathrm{XY}$ systems, it was shown that a $\mathrm{Y}$ chromosome-carried gene can negatively regulate one or more genes triggering female development. On the opposite side, in WZ/ZZ systems-based organisms, it is more likely that a gene carried by the $\mathrm{W}$ chromosome determines the female development.

However, Golenberg and West argued that neither SGM nor TGM are able to explain effectively a switch to a dioecius state starting from a gyno/andromonoecious condition (i.e., a single plant carries both hermaphrodite and female or male flowers) or from a unisexual flowers-based monoecious condition. It is in fact unlikely to observe different genotype combinations (e.g., $A a b b$ and $a a B b$ ) within individual floral meristems of the same plant [27]. In this case, it is more likely that either external environmental or internal physiological factors (i.e., hormones) directly or indirectly regulate the expression of one or more genes involved in sex determination. This behavior is also known as sex plasticity and the main masculinizing and feminizing effects produced by environmental stresses or hormonal treatments and have been brilliantly reviewed by Golenberg and West [27].

\section{Plant Species Supporting Models}

The advent of second and third generation sequencing technologies has made it possible to take giant steps in understanding the molecular and genetic mechanisms underlying the determination of sex in numerous plant species. In fact, the heterogamy that characterizes many sexual systems in dioecious plants requires, as a fundamental prerequisite, the ability to resolve diploid phases in heterozygous genotypes, in order to determine the genomic variants in the male and female SDRs. In the following chapters, we focus on some examples of plant species for which, thanks to advances in genomics, it was possible to finely characterize the SDRs and define the model at the basis of dioecy: Vitis spp. for the two-gene system and Populus spp. for the one-gene system.

\subsection{The Two-Gene Model in the Vitis Genus}

Vitis, with specific reference to the vinifera species, represent a particularly fascinating case as regards the evolution of the mating system, since a first event of switch from hermaphrodite progenitor to dioecious plant was followed, through domestication, by a second event of "reversion" to the hermaphrodite state.

The Vitis genus is divided into two subgenera: Muscadinia, with chromosomal number $2 n=40$, represented by a limited number of species, and Euvitis, with chromosomal number $2 \mathrm{n}=38$, divided into at least 28 species of wild grapevine in North America, 30 in Asia and 1 in Europe, $V$. vinifera L. ssp. sylvestris, the wild ancestor of all domesticated species [28]. All wild Vitis species are dioecious, showing separate male and female individuals, with known genetic dominance of the male allele $(\mathrm{M})$ over the hermaphroditic one $(\mathrm{H})$ which in turn is dominant over the female one (f). Conversely, Vitis vinifera ssp. vinifera has been selected, during domestication, in order to develop hermaphroditic flowers $[29,30]$. This transition of the mating system probably occurred $~ 8000$ years ago [31], following a rare recombination event between male $(\mathrm{M})$ and female $(\mathrm{F})$ haplotypes firstly hypothesized by Picq et al., and Henry et al. [32,33] and recently demonstrated by Zou et al. [34]. The 
evolution of perfect flowers as a fundamental trait in the history of $V$. vinifera domestication is related to the higher self-pollination efficiency of hermaphrodite plants with respect to monoicous ones, which in turn guarantees reliable and stable yields.

Therefore, within the genus Vitis there are three types of individuals: males with flowers with reduced pistils, devoid of stigma and style, females with flowers containing reflected anthers and stamens that produce sterile pollen, and hermaphrodites, within the $V$. vinifera clade, which have perfect flowers with both functioning sexual organs.

The study of genetic determinants of sex in grapevine represents an emblematic example of how genomics and the evolution of increasingly fine technological and bioinformatic approaches in Next Generation Sequencing, led to the identification of genes involved in the determination of sex and to the constitution of a model explaining the evolution of dioecy and the reversion to hermaphroditism in cultivated varieties.

Amongst the major limitations in the study of sex determination in the Vitis genus, is the fact that, until recently, there was a lack of whole genomic data for wild and cultivated grapevine, and the $V$. vinifera PN40024 reference genome represented only a partially assembled $\mathrm{f}$ haplotype since it was obtained from a highly homozygous hermaphrodite line, providing no insights into the structural variants (SVs) that distinguish heterozygous chromosomes [35]. The sex-determining region (SDR) in grapes had already been identified in multiple genetic and genomic studies [30,32,34,36,37] in the first decade of 2000, and was described as a nonrecombinant region of chromosome 2 spanning approximately $150 \mathrm{~kb}$ and containing between 15 and 20 genes [30,32].

The recent advent of third generation sequencing technologies such as single-molecule real-time sequencing (SMRT), their use in hybrid assemblies for de novo genomes to combine short-read sequence data with long-read sequence data, and the consequent availability of an increasing number of phased diploid genomes of $\mathrm{H}, \mathrm{M}$ and $\mathrm{f}$ genotypes, made it possible to finely analyze the SDR region in different grapevine species taking important steps forward in the comprehension of mechanisms underlining sex determination in grapevine [23,34,38]. Recently, Massonnet et al. [23] analyzed this region comparing 11 wild and cultivated grapevine genomes, revealing structural differences between the $\mathrm{M}, \mathrm{H}$ and $\mathrm{f}$ haplotypes, and suggested candidate genes for both male and female sterility. The most obvious difference between haplotypes was in the length of the nonrecombinant SDR region amongst sexes: all $\mathrm{f}$ haplotypes analyzed (12 in total) had a much shorter average length $(181.4 \pm 10.2 \mathrm{kbp})$ than $\mathrm{M}(425.9 \pm 274.6 \mathrm{kbp})$ and $\mathrm{H}(289.2 \pm 7.4 \mathrm{kbp})$ ones, reflecting the presence of several sex-linked structural variants (SVs). By using sequence alignments to the Cabernet Sauvignon H haplotype, the authors identified SNPs that associate perfectly with sex among Vitis spp [23]. In particular, an 8 bp deletion of the gene VviINP1 (INAPERTURATE POLLEN1) causing a premature STOP codon was proposed as the potential male sterility mutation in Vitis spp. Conversely, M-linked polymorphisms together with expression evidence, suggested the gene VviYABBY3, encoding for a transcriptional regulator, is the female sterility candidate. Following a similar approach, [39] Badouin et al., examined the SDR using a comparative genome approach in $V$. sylvestris and proposed a different candidate for female sterility: VviAPT3, a gene involved in the cytokinin pathway. Although functional characterization for the role of both $V v Y A B B Y 3$ and $V v i A P T 3$ are still lacking in grapevine, a support for the role of $V v Y A B B Y 3$ as the candidate gene for female sterility came from another pivotal study [34].

In this study, by means of Pacific Biosciences (PacBio) long-read assemblies, wholegenome bulked sequencing, population genetics, transcriptomics and machine-learning approaches, the grape sex-determining region (SDR) was analyzed in 12 Vitis genomes and its conservation was demonstrated across 556 genotypes (193 accessions from 47 wild grapevine species and 363 accessions of cultivated grapevine). According to the two-gene model of dioecy, the grapevine SDR, is precisely conserved across the entire Vitis genus, and it was confirmed as recombination-free in all wild species, as demonstrated in previous studies $[23,32,38]$. Conversely, distinct hermaphrodite $(\mathrm{H})$ haplotypes (H1 and H2) were found among vinifera cultivars, both chimeras of male $(\mathrm{M})$ and female (f) haplotypes. 
These two independent recombination events carry different genetic signatures which long predate the domestication of grapevine, suggesting independent evolutions of this trait in wild European grapevine gene pools prior to human domestication [34]. In addition, the allele-specific expression (ASE) analysis including genotypes with either the H1 or H2 haplotypes, the examination of the patterns of SNPs across hundreds of genotypes from all grapevine gene pools and the discovery of the $\mathrm{H} 2$ allele, give greater support to VviINP1 and $V v i Y A B B Y 3$ as candidate genes for male sterility and female sterility of this species (Figure 2).

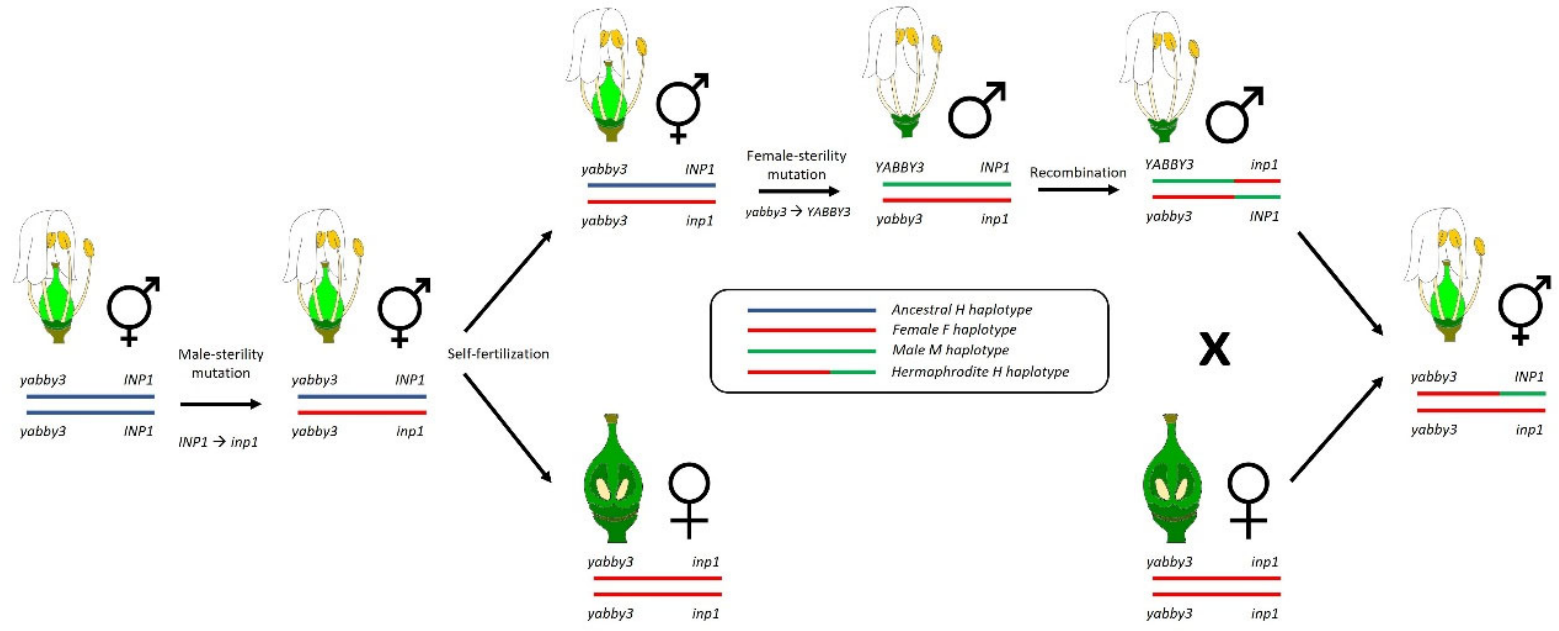

Figure 2. Schematic model of evolution of sex determination in grapevine. From left to right, a hermaphroditic ancestor gave rise to male-sterility mutation at the INP1 locus to produce gynodioecious individuals. The recessive male-sterility mutation is indicated as inp1. Conversely, a dominant female-sterility mutation at the $Y A B B Y 3$ locus originate male flowers. Based on a recent hypothesis [34], a rare recombination event occurred in a $V$. sylvestris male, leading to $H$ haplotype and hermaphrodite individuals in domesticated $V$. vinifera cultivars. Adapted from ref. [23].

\subsection{The One-Gene Model in Poplar Genus}

Almost all species belonging to the genus Populus are dioic plants, characterized by a male heterogametic (YX) system of sex determination. The only exception is white poplar (Populus alba), which presents a ZW system with heterogametic females [40]. In the last 20 years, many studies on sex determination in Populus genus were performed and several Populus species were reported with a male heterogametic configuration of sex mapped on chromosome 19. Nonetheless, the exact location of the SDR is variable between species: in P. trichocarpa and P. nigra (sections Tacamahaca and Aigeiros), it is located in the proximal telomeric end of chr19 [41,42]. Conversely, in P. tremula, P. tremuloides and P. alba (section Populus), the SDR in a pericentromeric region of chr19 [40,43,44]. Finally, in $P$. euphratica the SDR regions mapped on the telomeric region of chromosome 14 [45]. Similar to what happened in grapevine, the availability of third generation sequencing technologies enables the production of long reads and thus to solve diploid phases, allowing the genomic determination and comparison of the SD region in P. trichocarpa, $P$. deltoides, $P$. tremula, $P$. alba, P. euphratica and P. purpurea $[25,42,45]$.

Genome-wide association studies (GWAS) together with long read sequencing of the SD region led to the identification of a homolog of the A. thaliana gene pair ARABIDOPSIS RESPONSE REGULATOR 16 (ARR16/ARR17), a type A cytokinin response regulator. Amongst those genes located in the SD region $A R R 17$ represent an excellent candidate for sex determination $[41,46]$. As a matter of fact, recent studies revealed that genes involved in cytokinin signaling play important roles in the regulation of unisexual flower development in plants [47]. Whereas in all species analyzed the ARR17 gene on the female SDR is intact, the male-specific region of the $\mathrm{Y}$ chromosome carries partial duplicates of ARR17 arranged as inverted repeats [25]. The observation that (i) CRISPR/Cas9- mediated arr17 knockout in 
early flowering aspen lines, revert females to fully functional males [25] and (ii) long read sequencing and de novo assembly of a female white poplar (ZW) identified three complete copies of $A R R 17$ in the $\mathrm{W}$ chromosome-specific contig and no copies in the Z haplotype, suggests that the $A R R 17$ genes are more likely to function as a dominant promoter of female function [45]. In contrast, the $A R R$ gene fragments on the $\mathrm{Y}$ chromosome of $P$. euphratica, P. trichocarpa, $P$. deltoides and $P$. tremula may serve as a female suppressor by encoding an siRNA that targets the intact $A R R$ gene at the distal end of chromosome 19 , possibly by means of RNA-directed DNA methylation (RdDM). Thus, whether in the only female heterogametic species, $P$. alba, sex determination appears to be based on a simple presence/absence of $A R R 17$, in all other species it seems to be dependent on the suppression of functional $A R R$ gene by mans of RNA-directed DNA methylation caused by inverted duplicated $A R R$ pseudogenes on the male (Y) SDR haplotype (Figure 3).
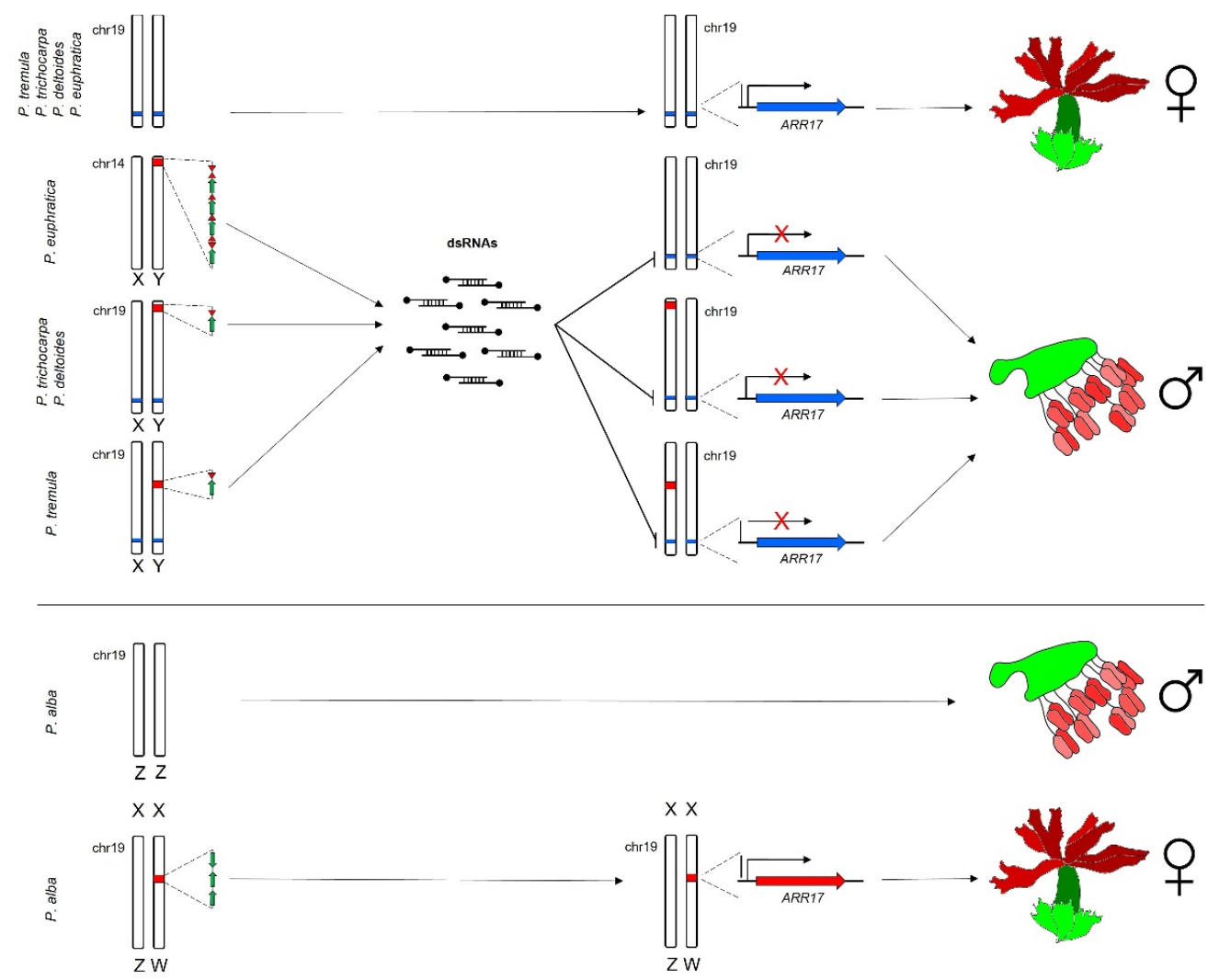

Figure 3. Schematic model of evolution of sex determination in Populus genus. In P. euphratica, $P$. trichocarpa, P. deltoides and P. tremula, partial inverted duplicates of the ARR17 gene on the Y SDR haplotype act as suppressors of female development by an siRNA-mediated silencing of the intact $A R R 17$ gene located on a different region of chr19. In P. alba, several intact ARR genes totally absent on the $\mathrm{Z}$ chromosome act as a dominant promoter of female function. Adapted from ref. [45].

\section{Conclusions}

In this brief excursus, which started with a brief tribute to Prospero Alpini, the pioneer of dioecism, we considered two plant species of great agronomic and forestry value, grapevine and poplar, highlighting the contribution that the most recent applications of genomics provided in deciphering this phenomenon. Novel molecular techniques such as third generation sequencing, together with next generation breeding techniques such as CRISPR/Cas9 are speedily becoming accessible, facilitating the identification of SDRs. On the one hand, long-read sequencing technologies such as Pacific Biosciences' (PacBio) single molecule real-time (SMRT) sequencing and Oxford Nanopore Technologies' (ONT) nanopore sequencing allow us to obtain phased, accurate and complete (including base modifications) genomes, condicio sine qua non the identification of structural variations (SVs) 
within the sex-determining region (SDR) would be hardly feasible. On the other hand, the ability to edit genomes in a targeted and precise manner is crucial for the functional characterization of candidate loci within the SDR and the consequent determination of key genes involved in sex configuration. It is therefore expected that the combination of sequencing and editing techniques, combined with the reduction of their costs and their complexity of application, will likely lead to the accurate determination of the mechanisms underlying dioecy in an increasing number of different plant species, laying the foundations for a unifying model capable of explaining this phenomenon in a transversal way.

Author Contributions: Conceptualization, G.B.; investigation, A.V. and F.P.; writing-original draft preparation, A.V. and F.P.; writing-review and editing, A.V., F.P., G.B. and M.L.; supervision, G.B.; project administration, G.B. All authors have read and agreed to the published version of the manuscript.

Funding: This research received no external funding.

Institutional Review Board Statement: Not applicable.

Informed Consent Statement: Not applicable.

Conflicts of Interest: The authors declare no conflict of interest.

\section{References}

1. Alpini, P. De Plantis Aegypti Liber; Venetiis, Apud Franciscum de Franciscis Senensem: Venetia, Italy, 1592.

2. WFO (2022): World Flora Online. Available online: http:/ / www.worldfloraonline.org/ (accessed on 15 January 2022 ).

3. Renner, S.S.; Ricklefs, R.E. Dioecy and its correlates in the flowering plants. Am. J. Bot. 1995, 82, 596-606. [CrossRef]

4. Villarreal, J.C.; Renner, S.S. Correlates of monoicy and dioicy in hornworts, the apparent sister group to vascular plants. BMC Evol. Biol. 2013, 13, 239. [CrossRef] [PubMed]

5. Walas, Ł.; Mandryk, W.; Thomas, P.A.; Tyrała-Wierucka, Ż.; Iszkuło, G. Sexual systems in gymnosperms: A review. Basic Appl. Ecol. 2018, 31, 1-9. [CrossRef]

6. Renner, S.S. The relative and absolute frequencies of angiosperm sexual systems: Dioecy, monoecy, gynodioecy, and an updated online database. Am. J. Bot. 2014, 101, 1588-1596. [CrossRef]

7. Käfer, J.; de Boer, H.; Mousset, S.; Kool, A.; Dufaÿ, M.; Marais, G.A.B. Dioecy is associated with higher diversification rates in flowering plants. J. Evol. Biol. 2014, 27, 1478-1490. [CrossRef]

8. Heilbuth, J.C. Lower Species Richness in Dioecious Clades. Am. Nat. 2000, 156, 221-241. [CrossRef]

9. Lewis, B.Y.D. Male Sterility in Natural Populations the Equilibrium Between Females and Hermaphrodites to be Expected with Different. New Phytol. 1941, 40, 56-63. [CrossRef]

10. Westergaard, M. The Mechanism of Sex Determination in Dioecious Flowering Plants. Adv. Genet. 1958, 9, 217-281. [CrossRef]

11. Endress, P.K.; Doyle, J.A. Reconstructing the ancestral angiosperm flower and its initial specializations. Am. J. Bot. 2009, 96, 22-66. [CrossRef]

12. Barcaccia, G.; Palumbo, F.; Sgorbati, S.; Albertini, E.; Pupilli, F. A Reappraisal of the Evolutionary and Developmental Pathway of Apomixis and Its Genetic Control in Angiosperms. Genes 2020, 11, 859. [CrossRef]

13. King, R.C.; Stansfield, W.D.; Mulligan, P.K. A Dictionary of Genetics, 7th ed.; Oxford: Oxford, UK, 2006.

14. He, L.; Jia, K.; Zhang, R.; Wang, Y.; Shi, T.; Li, Z.; Zeng, S.; Cai, X.; Wagner, N.D.; Hörandl, E.; et al. Chromosome-scale assembly of the genome of Salix dunnii reveals a male-heterogametic sex determination system on chromosome 7. Mol. Ecol. Resour. 2021, 21, 1966-1982. [CrossRef] [PubMed]

15. Hallingbäck, H.R.; Pucholt, P.; Ingvarsson, P.K.; Rönnberg-Wästljung, A.C.; Berlin, S. Genome-wide association mapping uncovers sex-associated copy number variation markers and female hemizygous regions on the $\mathrm{W}$ chromosome in Salix viminalis. BMC Genom. 2021, 22, 1-14. [CrossRef] [PubMed]

16. Slancarova, V.; Zdanska, J.; Janousek, B.; Talianova, M.; Zschach, C.; Zluvova, J.; Siroky, J.; Kovacova, V.; Blavet, H.; Danihelka, J.; et al. Evolution of Sex Determination Systems with Heterogametic Males and Females Insilene. Evolution 2013, 67, 3669-3677. [CrossRef] [PubMed]

17. Tamiru, M.; Natsume, S.; Takagi, H.; White, B.; Yaegashi, H.; Shimizu, M.; Yoshida, K.; Uemura, A.; Oikawa, K.; Abe, A.; et al. Genome sequencing of the staple food crop white Guinea yam enables the development of a molecular marker for sex determination. BMC Biol. 2017, 15, 1-20. [CrossRef]

18. Pennell, M.W.; Mank, J.E.; Peichel, C.L. Transitions in sex determination and sex chromosomes across vertebrate species. Mol. Ecol. 2018, 27, 3950-3963. [CrossRef] [PubMed]

19. Kottler, V.A.; Feron, R.; Nanda, I.; Klopp, C.; Du, K.; Kneitz, S.; Helmprobst, F.; Lamatsch, D.K.; Lopez-Roques, C.; Lluch, J.; et al. Independent Origin of XY and ZW Sex Determination. Genetics 2020, 214, 193-209. [CrossRef] 
20. Charlesworth, B.; Charlesworth, D. A Model for the Evolution of Dioecy and Gynodioecy Published by The University of Chicago Press for The American Society of Naturalists Stable. Am. Nat. 1978, 112, 975-997. [CrossRef]

21. Pannell, J.R. The Evolution and Maintenance of Androdioecy. Annu. Rev. Ecol. Syst. 2002, 33, 397-425. [CrossRef]

22. Akagi, T.; Henry, I.M.; Ohtani, H.; Morimoto, T.; Beppu, K.; Kataoka, I.; Tao, R. A Y-Encoded Suppressor of Feminization Arose via Lineage-Specific Duplication of a Cytokinin Response Regulator in Kiwifruit. Plant Cell 2018, 30, 780-795. [CrossRef]

23. Massonnet, M.; Cochetel, N.; Minio, A.; Vondras, A.M.; Lin, J.; Muyle, A.; Garcia, J.F.; Zhou, Y.; Delledonne, M.; Riaz, S.; et al. The genetic basis of sex determination in grapes. Nat. Commun. 2020, 11, 1-12. [CrossRef]

24. Torres, M.F.; Mathew, L.S.; Ahmed, I.; Al-Azwani, I.K.; Krueger, R.; Rivera-Nuñez, D.; Mohamoud, Y.A.; Clark, A.G.; Suhre, K.; Malek, J.A. Genus-wide sequencing supports a two-locus model for sex-determination in Phoenix. Nat. Commun. 2018, 9, 1-9. [CrossRef] [PubMed]

25. Müller, N.A.; Kersten, B.; Leite Montalvão, A.P.; Mähler, N.; Bernhardsson, C.; Bräutigam, K.; Carracedo Lorenzo, Z.; Hoenicka, H.; Kumar, V.; Mader, M.; et al. A single gene underlies the dynamic evolution of poplar sex determination. Nat. Plants 2020, 6, 630-637. [CrossRef] [PubMed]

26. Yu, L.; Ma, X.; Wadlington, W.; Ming, R. Identification of structural variation and polymorphisms of a sex co-segregating scaffold in spinach. Plant Reprod. 2021, 35, 19-30. [CrossRef] [PubMed]

27. Golenberg, E.M.; West, N.W. Hormonal interactions and gene regulation can link monoecy and environmental plasticity to the evolution of dioecy in plants. Am. J. Bot. 2013, 100, 1022-1037. [CrossRef]

28. Wan, Y.; Schwaninger, H.R.; Baldo, A.M.; Labate, J.; Zhong, G.-Y.; Simon, C.J. A phylogenetic analysis of the grape genus (Vitis L.) reveals broad reticulation and concurrent diversification during neogene and quaternary climate change. BMC Evol. Biol. 2013, 13, 1-20. [CrossRef]

29. Coito, J.L.; da Silva, H.S.G.; Ramos, M.J.N.; Montez, M.; Cunha, J.; Amancio, S.; Costa, M.M.R.; Rocheta, M. Vitis Flower Sex Specification Acts Downstream and Independently of the ABCDE Model Genes. Front. Plant Sci. 2018, 9, 1-20. [CrossRef]

30. Fechter, I.; Hausmann, L.; Daum, M.; Sörensen, T.R.; Viehöver, P.; Weisshaar, B.; Töpfer, R. Candidate genes within a 143 kb region of the flower sex locus in Vitis. Mol. Genet. Genom. 2012, 287, 247-259. [CrossRef]

31. This, P.; Lacombe, T.; Thomas, M.R. Historical origins and genetic diversity of wine grapes. Trends Genet. 2006, 22, 511-519. [CrossRef]

32. Picq, S.; Santoni, S.; Lacombe, T.; Latreille, M.; Weber, A.; Ardisson, M.; Ivorra, S.; Maghradze, D.; Arroyo-Garcia, R.; Chatelet, P.; et al. A small XY chromosomal region explains sex determination in wild dioecious. BMC Plant Biol. 2014, 14, 1-17. [CrossRef]

33. Henry, I.M.; Akagi, T.; Tao, R.; Comai, L. One Hundred Ways to Invent the Sexes: Theoretical and Observed Paths to Dioecy in Plants. Annu. Rev. Plant Biol. 2018, 69, 553-575. [CrossRef]

34. Zou, C.; Massonnet, M.; Minio, A.; Patel, S.; Llaca, V.; Karn, A.; Gouker, F.; Cadle-Davidson, L.; Reisch, B.; Fennell, A.; et al. Multiple independent recombinations led to hermaphroditism in grapevine. Proc. Natl. Acad. Sci. USA 2021, 118. [CrossRef] [PubMed]

35. Jaillon, O.; Aury, J.M.; Noel, B.; Policriti, A.; Clepet, C.; Casagrande, A.; Choisne, N.; Aubourg, S.; Vitulo, N.; Jubin, C.; et al. The grapevine genome sequence suggests ancestral hexaploidization in major angiosperm phyla. Nature 2007, 449, 463-467. [CrossRef] [PubMed]

36. Battilana, J.; Lorenzi, S.; Moreira, F.M.; Moreno-Sanz, P.; Failla, O.; Emanuelli, F.; Grando, M.S. Linkage Mapping and Molecular Diversity at the Flower Sex Locus in Wild and Cultivated Grapevine Reveal a Prominent SSR Haplotype in Hermaphrodite Plants. Mol. Biotechnol. 2013, 54, 1031-1037. [CrossRef]

37. Riaz, S.; Krivanek, A.F.; Xu, K.; Walker, M.A. Refined mapping of the Pierce's disease resistance locus, PdR1, and Sex on an extended genetic map of Vitis rupestris $\times$ V. arizonica. Theor. Appl. Genet. 2006, 113, 1317-1329. [CrossRef] [PubMed]

38. Zhou, Y.; Minio, A.; Massonnet, M.; Solares, E.; Lv, Y.; Beridze, T.; Cantu, D.; Gaut, B.S. The population genetics of structural variants in grapevine domestication. Nat. Plants 2019, 5, 965-979. [CrossRef] [PubMed]

39. Badouin, H.; Velt, A.; Gindraud, F.; Flutre, T.; Dumas, V.; Vautrin, S.; Marande, W.; Corbi, J.; Sallet, E.; Ganofsky, J.; et al. The wild grape genome sequence provides insights into the transition from dioecy to hermaphroditism during grape domestication. Genome Biol. 2020, 21, 1-24. [CrossRef]

40. Paolucci, I.; Gaudet, M.; Jorge, V.; Beritognolo, I.; Terzoli, S.; Kuzminsky, E.; Muleo, R.; Mugnozza, G.S.; Sabatti, M. Genetic linkage maps of Populus alba L. and comparative mapping analysis of sex determination across Populus species. Tree Genet. Genomes 2010, 6, 863-875. [CrossRef]

41. Geraldes, A.; Hefer, C.; Capron, A.; Kolosova, N.; Martinez-Nuñez, F.; Soolanayakanahally, R.Y.; Stanton, B.J.; Guy, R.D.; Mansfield, S.; Douglas, C.J.; et al. Recent Y chromosome divergence despite ancient origin of dioecy in poplars (Populus). Mol. Ecol. 2015, 24, 3243-3256. [CrossRef]

42. Zhou, R.; Macaya-Sanz, D.; Schmutz, J.; Jenkins, J.W.; Tuskan, G.A.; DiFazio, S.P. Sequencing and Analysis of the Sex Determination Region of Populus trichocarpa. Genes 2020, 11, 843. [CrossRef]

43. Pakull, B.; Groppe, K.; Meyer, M.; Markussen, T.; Fladung, M. Genetic linkage mapping in aspen (Populus tremula L. and Populus tremuloides Michx.). Tree Genet. Genomes 2009, 5, 505-515. [CrossRef]

44. Kersten, B.; Pakull, B.; Groppe, K.; Lueneburg, J.; Fladung, M. The sex-linked region in Populus tremuloides Turesson 141 corresponds to a pericentromeric region of about two million base pairs on P. trichocarpa chromosome 19. Plant Biol. 2013, 16, 411-418. [CrossRef] [PubMed] 
45. Yang, W.; Wang, D.; Li, Y.; Zhang, Z.; Tong, S.; Li, M.; Zhang, X.; Zhang, L.; Ren, L.; Ma, X.; et al. A General Model to Explain Repeated Turnovers of Sex Determination in the Salicaceae. Mol. Biol. Evol. 2020, 38, 968-980. [CrossRef] [PubMed]

46. McKown, A.D.; Klápště, J.; Guy, R.D.; Soolanayakanahally, R.Y.; La Mantia, J.; Porth, I.; Skyba, O.; Unda, F.; Douglas, C.J.; El-Kassaby, Y.A.; et al. Sexual homomorphism in dioecious trees: Extensive tests fail to detect sexual dimorphism in Populus. Sci. Rep. 2017, 7, 1831. [CrossRef] [PubMed]

47. Feng, G.; Sanderson, B.; Keefover-Ring, K.; Liu, J.; Ma, T.; Yin, T.; Smart, L.B.; DiFazio, S.P.; Olson, M.S. Pathways to sex determination in plants: How many roads lead to Rome? Curr. Opin. Plant Biol. 2020, 54, 61-68. [CrossRef] 